Article

\title{
Assessing the Contribution of Innovative Technologies to Sustainable Development for Planning and Decision-Making Processes: A Set of Indicators to Describe the Performance of Sustainable Urban Infrastructures (ISI)
}

\author{
Ulrike Schinkel *, Nadja Becker, Manuel Trapp and Mike Speck
}

Citation: Schinkel, U.; Becker, N.; Trapp, M.; Speck, M. Assessing the Contribution of Innovative Technologies to Sustainable Development for Planning and Decision-Making Processes: A Set of Indicators to Describe the Performance of Sustainable Urban Infrastructures (ISI). Sustainability 2022, 14, 1966. https://doi.org/ $10.3390 /$ su14041966

Academic Editor: Víctor Yepes

Received: 20 January 2022

Accepted: 7 February 2022

Published: 9 February 2022

Publisher's Note: MDPI stays neutral with regard to jurisdictional claims in published maps and institutional affiliations.

Copyright: () 2022 by the authors Licensee MDPI, Basel, Switzerland. This article is an open access article distributed under the terms and conditions of the Creative Commons Attribution (CC BY) license (https:// creativecommons.org/licenses/by/ $4.0 /)$.
Infrastructure and Municipal Development, IZES gGmbH, 66115 Saarbrücken, Germany; becker@izes.de (N.B.); mtrapp@izes.de (M.T.); speck@izes.de (M.S.)

* Correspondence: schinkel@izes.de

\begin{abstract}
The sustainable development of our cities and regions has become an integral part of the current debate. To achieve the sustainability goals, however, the development of sustainable technologies and infrastructures as well as decisive municipal action at the local level are essential. The research project VertiKKA ("Vertical Air Conditioning and Wastewater Treatment System"), sponsored by the German Ministry of Education and Research, addresses both technology development and the integration of innovative technologies and infrastructures into urban planning and decisionmaking processes. As a result, a set of indicators was developed that allows the assessment of urban infrastructures and technologies and their contribution to sustainable development. This article presents the "set of indicators for sustainable urban infrastructures" (ISI). ISI is based on the results of literature and policy review but was further developed and tailored to urban infrastructures and technologies. ISI considers the ecological, economic, and social dimension of sustainability to be of equal importance; in addition, ISI places particular emphasis on looking at the technology development process and on the creation of supportive governance structures for implementation. In order to create a link between research and practice, the applicability of ISI to the VertiKKA technology is critically reflected.
\end{abstract}

Keywords: sustainable urban development; sustainability assessment; sustainable urban infrastructures; life cycle assessment (LCA); life cycle costing (LCC); urban governance; valuation of ecosystem services; VertiKKA

\section{Introduction}

The beginnings of sustainability assessment date back to the 1990s, e.g., to the "Bellagio Principles-Guidelines for Practical Assessment of Progress Toward Sustainable Development" [1] developed by an international group of measurement practitioners and researchers and to the approach of the National Research Council of the USA [2], which aimed at making sustainable development observable and measurable. Since then, many different approaches to sustainability assessment have emerged for different contexts and fields of action, e.g., for the building sector [3] and urban development [4-7], for organisations and project management [8] as well as for policymaking [9,10], among others.

Sustainability assessments are usually based on sets of sustainability indicators, which-depending on the objective of the assessment-are developed from different perspectives and use diverse approaches as well as individual data collection methods. Waas et al. [11] summarise and systematise the multitude of objectives, perspectives, and approaches for the development of sustainability indicators and work out dichotomies between descriptive and normative, quantitative and qualitative, objective and subjective, bottom-up and top-down developed as well as between ex-ante and ex-post sustainability indicators. 
However, Waas et al. [11] emphasize that despite the diverse political commitments and the continuing popularity of the sustainability debate, actual comprehensive achievement of the goals has so far failed to materialise. Therefore, they argue that in order to truly achieve sustainable development, it is necessary to make sustainability assessments or sustainability indicators part of decision-making.

This is where the "set of indicators for sustainable urban infrastructures" (ISI) presented in this article comes in. On the one hand, the focus of ISI is to determine the contribution of innovative urban technologies and infrastructures to sustainable development using a set of sustainability indicators. On the other hand, however, ISI pursues in particular the goal of supporting planning decisions, working towards the creation of an innovation-friendly and sustainability oriented (institutional) environment and, thus, advancing the implementation of technologies for the benefit of sustainable urban development.

While ISI pursues these ambitious goals, the development process has shown that the actual effectiveness and usability of the individual indicators depend significantly on the type and amount of data required. Therefore, manageability is a major challenge for the development of ISI. The proposed indicators are still at a general stage of elaboration. The indicators are not yet fully described, nor have the corresponding parameters been differentiated. This will happen in the context of further research activities, by testing ISI in practical case studies and through the active integration of stakeholders in the discussion process.

ISI was developed within the framework of the research project VertiKKA ("Vertical Air Conditioning and Wastewater Treatment System"). The VertiKKA project is one of the 12 research projects currently funded under the RES:Z programme (RES:Z stands for the "Resource-efficient urban districts for the future" initiative of the German Federal Ministry of Education and Research) and focuses on the development of multifunctional green façade elements using greywater for irrigation in combination with façade photovoltaics for the case city Cologne. The technology solution is expected to contribute to the relief of drainage infrastructures, to rainwater retention, to the improvement of the microclimate and to the reduction of the urban heat island effect, to improved air quality and to the production of renewable energies, and, consequently, to sustainable urban development. Although ISI was developed as a part of the VertiKKA project, it is not specifically tailored to this technology, but allows for the consideration of urban technologies and infrastructures in general.

\section{Materials and Methods}

ISI was developed using a mix of methods, combining theory work (literature and policy review) with creative research activities (advancement of existing sets of indicators and concept development). ISI follows a multi-criteria approach and is, thus, based on a set of sustainability indicators, which are grouped according to impact categories.

The most frequently quoted classic definition of sustainable development that gained widespread acceptance is provided by the Brundtland report: "Sustainable development is development that meets the needs of the present without comprising the ability of future generations to meet their own needs" [12] (p. 43). Sustainable development aims at bringing the economic, social, and ecological sectors together in a balanced way.

ISI incorporates the three dimensions of sustainability and considers relevant prior work for each dimension. The following paragraphs provide an overview of the literature sources used:

The ecological dimension of sustainability analyses the environmental impact of urban technologies. Emissions to soil, water, and air as well as the resource consumption of the technology under consideration are recorded and their environmental impact is assessed. The central element of the ecological dimension is life cycle assessment (LCA), a standardised method for quantifying the environmental impacts of products and services over their entire life cycle from cradle to grave or cradle to cradle. The LCA methodology 
has been practised already since the early 1970s as "cradle-to-grave assessment" [13]. Since then, the methodology of LCA has continued to evolve. Further efforts according to Heijungs et al. [14], Haes et al. [15,16], Guinée [17,18] as well as ISO [19] led in 1997 to the first definition of the principles, the framework, and the basic requirements for the treatment of the individual LCA phases, which were finally laid down in the standard ISO $14040 \mathrm{ff}$. (in particular ISO 14040:2006 [20]; ISO 14044:2006 [21]). The methodology was refined over time (see, e.g., the ILCD Handbook [22,23] and the JRC Reference Report [24]) and is still being further developed today $[25,26]$. The development of an appropriate set of indicators for the ecological dimension of ISI is based on the ILCD-Handbook and on the detailed description of the life cycle impact assessment (LCIA) methods [27-29]. The LCA methodology for the evaluation of products and services with regard to sustainable neighbourhood and urban development can also be found in various certification systems for buildings and components, such as DGNB [30], LEED [31], and BREEAM [32].

Urban areas are drivers for economic development and provide high potentials for regional value creation and change towards more sustainable economic action. The economic dimension of sustainability looks at the economic performance of the technology as well as at resource efficiency, circular economy, employment effects, vulnerability, and external effects.

For the development of the economic set of indicators of ISI, secondary resources of existing sustainability assessments and respective sets of indicators were studied. Carius et al. [33] focus on the regional perspective of the sustainability performance with the regional impact assessment (RIA); the economic dimension of RIA focuses on investment/profitability/value added, stability of market, local economy/trade balance, and resources. The Food and Agriculture Organization of the United Nations [34] developed guidelines for the sustainability assessment of food and agriculture systems and focuses in its economic dimension on investment, vulnerability, product safety and quality as well as on local economy. The National Sustainable Development Strategy of Germany $[35,36]$ delivers various indicators to measure Germany's contribution to achieving the 17 Sustainable Development Goals (SDGs). Onat et al. [37] and Wulf et al. [38] assess sustainability and its economic dimension with the life cycle approach. Wulf et al. [38] discuss indicators of life cycle costing (LCC). The Society of Environmental Toxicology and Chemistry (SETAC) developed a code of practice for LCC [39]. Besides these reviews, methodological and policy papers, also case studies, were examined, e.g., Becker et al. [40] and Bandanaa et al. [41]. Geneletti et al. [42] and Landsberg et al. [43] deal with ecosystem services and their integration into sustainability assessments. TEEB [44], Kehl [45], and Costanza et al. [46] give an overview on the research regarding ecosystem services and their valuation.

The social dimension of sustainability in interaction with urban, neighbourhood, and technological development is the least firmly defined. Therefore, theoretical work was reviewed in order to develop a better understanding of social sustainability (e.g., [47-50]). The work of Vallance et al. [51] is particularly noteworthy as it derives three different strands of social sustainability, namely "development sustainability", "bridge sustainability" and "maintenance sustainability", which are of great value for the development of the set of indicators of ISI. Spangenberg and Omann [52] distinguish between the "human" and the "societal" domain of social sustainability and highlight the role of the institutional setting; moreover, their work provides a useful theoretical framework for the development of the set of indicators as a multi-criteria assessment approach.

In addition to the literature review, which mainly reflects the perspective of researchers, relevant policy papers were examined. These sources include, in particular, strategies and plans of different levels of action whose development goals are oriented towards the SDGs of the United Nations. Besides the 2030 Agenda for Sustainable Development [53]), the following sources were examined: The New Leipzig Charter [54], the National Sustainable Development Strategy of Germany [35,36]), and the Sustainable Development Strategy of North Rhine-Westphalia [55] (as VertiKKA was originally developed for the case 
city Cologne). Moreover, publications of the "SDG-Indikatoren für Kommunen" ("SDG indicators for municipalities") project, led by the Bertelsmann Stiftung [56]) were examined. The SDGs, targets, and indicators, which seemed to make sense for the assessment of urban technologies and infrastructures, were directly or indirectly incorporated into ISI.

Based on the results of literature and policy review and of the examination of existing approaches, a first set of impact categories and indicators was developed. Existing methods, in particular LCA and DIN standards $[57,58]$ as well as LCC, were integrated in the development of the impact categories and indicators.

In a last step, the applicability of the set of indicators to the specific VertiKKA solution was tested.

\section{Results}

This chapter, which presents the ISI in detail, starts with the formulation of the main aim of the set of indicators. The following sub-chapters focus on the theoretical derivation and on the methodical structure of ISI as well as on the set of indicators itself. The chapter concludes with a critical reflection on the applicability of ISI to the VertiKKA solution and on the contribution of ISI to sustainable and resource-efficient neighbourhoods.

\subsection{Aim of ISI}

ISI focuses on innovative urban technologies and supports the assessment of the technologies' contribution to the sustainable development of cities, partly against the background of their own development objectives. Thus, there is a clear local reference for the assessment.

ISI also aims at supporting planning and decision-making in political bodies and administrations as well as in the private sector. Comparable with the concept of Spangenberg and Omann [52] of multi criteria assessment approaches, ISI facilitates complex assessment and decision-making processes in which different objectives may compete with each other and in which chosen impact categories and indicators may also be in conflict with each other. Therefore, it is unlikely that the one best solution can be found when comparing different technology options.

The aim of the ISI is to bring transparency into planning and decision-making processes, taking into account not only quantitative but also qualitative, multidimensional, incomparable, or non-measurable influencing variables, and to help minimising trade-offs. Eventually, ISI promotes the investment in innovative technologies and the creation of supportive governance structures and, thus, contributes to the development of resourceefficient and sustainable cities and neighbourhoods.

\subsection{Theoretical Derivation and Methodical Structure of ISI}

This chapter is dedicated to the derivation of the approach and structure of ISI. For a better understanding, references are made between the theoretical derivation and the concrete set of indicators, which will be discussed in the next chapter.

\subsubsection{The Ecological Dimension of Sustainability}

The methodology of LCA is used to determine the indicators relevant for the ecological dimension of ISI. LCA is a well-established method to quantify all relevant emissions generated and all resources used or consumed by the investigated technology or infrastructure throughout its entire life cycle. Based on the results of the LCA, the environmental and health impacts as well as the resource consumption associated with the investigated technology can be evaluated. The LCA follows the aforementioned ISO standard $[57,58]$ and the ILCD manual [22-28]. The assessment is carried out according to the LCA method applying the following steps:

1. Definition of goal, scope, and other important basic parameters like for instance the definition of the function unit or the data quality. 
2. Inventory analysis (LCI), which means the quantification of all consumed raw material and generated emissions over the entire life cycle.

3. Life cycle impact assessment (LCIA) as an assessment of the environmental consequences of the consumption of raw materials and generated emissions.

4. Interpretation of the achieved results.

The indicators of the ecological dimension are derived on the basis of the LCA impact categories defined in step 3. The LCA methodology according to EC-JRC-IES [22] distinguishes between two different characterisation models. The midpoint approach is more problem-oriented and assesses the environmental impacts at the intermediate level of the impact chain, e.g., global warming, while the endpoint approach is damage-oriented and focuses on the final impacts on defined protection categories, e.g., human health. The ILCD manual [27] defines the following so-called mid-point impact categories:

- Climate change

- Ozone depletion

- Human toxicity, cancer/non-cancer effects

- Particulate matter/respiratory inorganics

- Ionising radiation, human health/ecosystems

- Photochemical ozone formation

- Acidification

- Eutrophication, terrestrial

- Eutrophication, aquatic

- Ecotoxicity, freshwater

- Ecotoxicity, terrestrial and marine

- Land use

- $\quad$ Resource depletion (water, mineral, fossil and renewable)

ISI is fundamentally based on the midpoint impact categories of the ILCD manual but adapts the selection of indicators according to the respective study and the respective technology as well as to the data availability in step two (LCI). A large number of established impact assessment methods (e.g., CML [59], ReCiPe [60] and EDIP [61]) are available for calculating environmental impacts in the context of LCA [28,62]. Some of the methods are constantly being adapted or further developed; consequently, in some cases, they differ significantly with regard to the recording of impacts, the choice of indicators for some impact categories, and the environmental models used to describe the indicators. The choice of the LCIA method (midpoint and/or endpoint approach) needs to be made according to the type of technology. ReCiPe [60], for example, is a very extensive and current method for both the midpoint and the endpoint approach.

\subsubsection{The Economic Dimension of Sustainability}

The economic analysis of the investigated urban technology starts with an LCC. Although LCC is the "oldest form of evaluation" of economic impacts [38] (p.18), there is no standard approach, but several methods and standards have been established [63], e.g., VDI 2884 [64], Total Cost of Ownership, VDMA 34160 [65], DIN EN 60300-3-3 [66]. LCC is defined as the "process of economic analysis to assess the life cycle cost of a product over its life cycle" [66] (p. 7), considering all incoming and outgoing payments. ISI includes a computation of total costs of the life cycle from the consumer perspective (i.e., consideration of the life cycle of a product from cradle to grave/cradle, see, e.g., Plinke and Utzig [67]), discounted to their present value with an adequate discount factor. This calculation provides statements on (present values of) initial investment costs, operating costs (including maintenance), and dismantling costs. Further, it is the basis for an investment analysis: Depending on the context, different indicators can be used to picture the economic performance of the investigated technology, e.g., internal rate of return, annuity, and/or payback period. Information on sensitivities (i.e., the impact of changes in selected input parameters on the results) will complete this picture. 
Macro-economic impacts are addressed in the following impact categories, inspired and developed from previous assessments and reviews [33-38,40,41]. Moreover, employment effects in the region are quantified. Employment is an important economic figure for economic development but has also a significant influence on the social dimension. Vulnerabilities are demonstrated regarding financial structures and regional in-/dependence. Financial flows and market structures will be analysed to disclose inequalities, the stability of supply and demand as well as the contribution to public welfare.

To assess the sustainability performance of the investigated technology, also the supply chain of the different components needs to be considered by determining the shares (of total costs) of renewable, fair traded, recyclable, secondary, and regional resources and materials (analogous to the quantitative assessment in the ecological dimension). This is especially important to show the potential of the technology for the implementation of a regional circular economy and cradle-to-cradle approaches in urban areas. Regional value creation, regional job creation, and the closing of regional material cycles is crucial for urban sustainable development.

Landsberg et al. [43] examine the increasing importance of the integration of ecosystem services into impact assessments to draw a more comprehensive and realistic picture of "a project's immediate and long-term impacts". Geneletti et al. [42] state that, so far, this integration is not prevailing in practice due to several barriers including a lack of instructional support and acceptance, resources, and capacity as well as established norms and assessment routines. For the development of a new sustainability set of indicators, the integration of ecosystem services is essential as the subject is gaining increasing attention, e.g., through the UN decade on preventing, haltering, and reversing the degradation of ecosystems worldwide [68]. Further, it is important to draw attention to the uncompensated public benefits of urban technologies and their potential public risks that may not be compensated by the polluter. The authors decided to include the quantification and monetisation of ecosystem services in the economic dimension and leave it out in the ecological dimension to avoid double counting of the same impacts in physical and financial terms (see e.g., [39] (p. 390)).

Ecosystem services can be defined as the "benefits that humans derive from nature" [44] (p. 1) and with relevance to their valuation, they can be divided into provisioning, regulating, and cultural services [44,46]. A range of economic valuation methods (market prices, replacement costs, damage costs), participatory approaches (stated preferences), and secondary analyses (revealed preferences, benefit transfer) can be used for the valuation of the ecosystem services that originate from the investigated urban technology (cf. [44] (p. 22), [45] (p. 124ff.)). The valuation not only includes a monetary classification of the ecosystem services but also a holistic assessment of qualitative and quantitative benefits as a decision basis and road map for urban decision makers.

Economic assessments are often limited to quantifiable economic measures under the paradigms of economic growth and profit maximisation, not examining the quality of financial and material flows, occurring external effects as well as the contribution to economic resilience and a regional circular economy. Under the paradigm of strong sustainability [69] (p. 146ff.), natural capital cannot be substituted by man-made capital and needs to be conserved to protect possible future preferences. Therefore, it is essential to highlight the importance and the value of natural capital by integrating the contribution of an urban technology to the conservation of natural capital stocks in the economic performance rating.

The economic dimension of ISI combines various previous concepts including both the analysis of direct costs resulting from the urban technology from a life cycle perspective as well as the assessment of macro-economic impacts and the valuation of ecosystem services of the urban technology. 


\subsubsection{The Social Dimension of Sustainability}

The social dimension of sustainable development is the most elusive so far. However, various concepts for the evaluation of innovative technologies and resource -efficient neighbourhoods paying particular attention to the effects on the social dimension of sustainability exist.

Vallance et al. [51] divide three different conceptual strands of social sustainability, which all have their justification against the background of technology, infrastructure, and urban and neighbourhood development.

The first strand determined by Vallance et al. [51] is called "development social sustainability". This strand highlights the importance of meeting basic tangible and less tangible needs as the basis of social sustainability. Underlying this strand is the conviction that only when essential basic needs are met, environmental issues can be addressed. Poverty and underdevelopment-in contrast-act as barriers for the uptake of green technologies [70] (cited in [51]) and for securing better social and environmental outcomes. ISI takes up aspects of the "development social sustainability" and translates them into impact categories (and indicators) that focus on the affordability of the technology ("equal access to the technology") and its contribution to a healthy living environment ("human health"), among others. Moreover, ISI addresses the possible creation of jobs through the technology ("potential for the creation of 'good' jobs in the region"), its usefulness in the local context ("implementation potential") and its contribution to people's wellbeing ("life satisfaction").

The second strand is named "bridge social sustainability". As the name suggests, this strand focuses on the improvement of the connections between people and the environment. "Bridge social sustainability" moves the leverage of human potential for the achievement of positive environmental outcomes, the promotion of eco-friendly behaviour or environmental ethics, to the centre. However, Vallance et al. [51] make a distinction between transformative approaches, which "re-imagine" people's relationships with the environment, and non-transformative approaches, which focus on behaviour change or on the adoption of technological innovations rather than on the change of lifestyles of beliefs. The value of raising awareness and changing unsustainable consumption patterns is also given great importance in ISI. Therefore, the set of indicators takes up various related aspects, such as the contribution of the technology and its creation process to environmental education ("environmental education and awareness raising") or the approval of environmental policy issues ("acceptance of new technologies").

The third strand is called "maintenance social sustainability" and refers to traditions, practices, preferences, and places people would like to see maintained (or improved) as they play a major role for their quality of life, social networks, and living environment etc. In this context, Vallance et al. [51] point out that the discussion on sustainable development contains contradictions as many strategies and plans to promote sustainable development or to protect the environment and resources are in contradiction to the preservation of preferred or established behaviour patterns, values, and traditions. However, since the success of the strategies and plans depends to a large extent on the social acceptance of the population, they require adequate support from the population in order to be really sustainable. ISI accepts the contradictions that arise from the sustainability debate and emphasizes the value of the active participation of different stakeholder groups in technology development so that as many perspectives as possible can be incorporated into it. Furthermore, aspects that address and support the preservation of functioning neighbourhoods and prevent segregation ("stability of neighbourhoods") are included in the set of indicators.

Spangenberg and Omann [52], on the other hand, point out that a consensus is emerging, in various research fields, that the framework for sustainability assessments no longer comprises only three dimensions, but creates a four-dimensional space. While the economy and the environment occupy two different axes, the social axis is divided into the "human" and the "societal" axis. The "human" axis focuses on the quality of life (including social 
security) as well as on the integration and involvement of individuals in society; the "societal" axis, in contrast, refers to societal institutions, which include, e.g., organisations, mechanisms, and orientations, and thematises the empowerment of individuals as well as their participation and involvement in public decision-making. Kanie et al. [71] (p. 6) (cited in Glass and Newig [72]) emphasise the role of governance in achieving sustainability goals even more clearly and refer to it as the "fourth pillar of sustainable development". This theoretical separation between aspects that affect the quality of life and those that relate to the creation or strengthening of institutions and suitable governance structures also makes sense for ISI.

The theoretical derivation shows that different perspectives can be taken for the evaluation of a technology solution from the point of view of the social dimension. Basically, an innovative urban technology should contribute to the improvement of public services, living conditions, and urban quality without causing financial hardship for the inhabitants or-due to high costs—only being available to a part of society.

Closely linked to this is the consideration or anticipation of possible dynamics that accompany the implementation of the technology, e.g., displacement effects through the upgrading and image gain of neighbourhoods or the (forced) change of values and living habits. At the same time, and this contradicts the previous point, an innovative technology should-ideally—also contribute to environmental education and an ecological way of life (which includes behaviour change).

The social dimension should-in addition to analysing the direct and indirect effects of an innovative technology - also include the way in which the technology is created and how the population or different user groups are involved in the development process. Direct participation in the development process may have the effect of increasing the acceptance of the technology, as articulated user requirements and concerns can be taken into account.

Furthermore, it has to be assessed which instruments, mechanisms, and processes need to be created and how the political and legal framework would have to be changed in order to implement the technology-in a sustainable way-in the future.

In order to structure the impact categories of the social dimension in a meaningful and clear way, they are placed in two different pillars. The first pillar contains the impact categories that enable the assessment of the technology with regard to the direct and indirect, measurable, and anticipated impacts of the technology on the urban society. The second pillar focuses on the impact categories that can be used to analyse and describe the technology development process ("engagement of the urban society in the technology development process") and necessary changes in the governance system ("integration of innovative technologies into municipal action", "enablement of the equal access to the technology", "initiation of new partnerships and collaborations") as well as activities that may initiate behavioural changes ("active change of consumption patterns"). In principle, the impact categories summarised in this pillar can also serve in part as points of reference for the process design of similar research and development projects.

\subsubsection{Sustainability Indicators Developed for ISI}

The methodological approach of ISI deals openly with the dichotomies summarised in Waas et al. [11]:

ISI uses normative sustainability indicators: Descriptive indicators describe an actual situation while normative indicators compare an actual situation with a desired one [73] (cited in [11]). All indicators compiled in ISI are linked to the SDGs and are, therefore, normative indicators.

ISI integrates quantitative and qualitative sustainability indicators: Quantitative indicators are based on quantitative data and express objectives and goals in numerical values. Qualitative indicators, in contrast, are based on qualitative data; objectives and goals can also be formulated as non-numerical values. ISI uses quantitative indicators, e.g., to compare the state of ecosystems before and after the implementation of a technology solution or to consider its economic viability. Qualitative indicators are similarly important, 
however, because they can be used to express assessments and evaluations as well as qualitative claims that cannot be adequately captured with quantitative indicators. In ISI, qualitative indicators are used particularly often but not exclusively for the assessment of the technology development process and the changes in the governance structure, as the quality of the process and the instruments, mechanisms, and structures created is more important and meaningful than their number.

ISI uses objective and subjective sustainability indicators: The distinction between objective and subjective indicators plays a significant role in sustainability assessments. Objective indicators are usually measured by instruments; subjective indicators, on the other hand, are based on individual perceptions and cannot be verified or disproved by other individuals or instruments. While objective indicators are mostly measured quantitatively, subjective indicators are predominantly assessed in a qualitative way [74] (cited [11]). ISI uses both, objective and subjective indicators; on the one hand, ISI attaches importance to measurable key figures that demonstrate, among other things, the technology's contribution to sustainable development or its true costs and economic viability, but, on the other hand, also to the mapping of subjective perceptions and apprehension of stakeholders and users.

ISI was developed top-down: It plays an essential role whether indicators are developed from an expert perspective (top-down) or from the perspective of the stakeholders (bottom-up). Waas et al. [11] underline the usefulness of their combination and suggest the inclusion of different perspectives and the development of so-called "hybrid" indicators. ISI was developed almost entirely by researchers, but with the involvement of the research partners (including representatives of the City of Cologne and Cologne Municipal Drainage Works). However, in order to break its strong academic focus, ISI offers the possibility of adaptation and active involvement of different stakeholders in the process.

ISI's indicators can be used as ex-ante and ex-post indicators: Ex-ante indicators provide information for assessing the future effects of decisions made today and enable a choice between different options. Ex-post indicators, on the other hand, come into play after decisions have been made and help to evaluate their practical implementation. The majority of indicators developed for ISI allow for both ex-ante and ex-post evaluation. They can be used as targets for the development of the technology and for the associated processes in the planning phase as well as for evaluating the achievement of the targets during and after the implementation phase.

\subsection{The Set of Indicators for Sustainable Urban Infrastructures (ISI)}

In this chapter, the ISI indicators are presented in detail. To develop ISI, impact categories were first determined for the three dimensions of sustainability; in a next step, concrete indicators were developed.

ISI consists of four pillars (see Figure 1); the first two are dedicated to the ecological and the economic dimension. As derived above, the impact categories and indicators for the social dimension are divided into two thematic pillars: The third pillar focuses on the effects of the technology on urban society, while the fourth pillar looks at the technology's development process and the (necessary) changes in the governance structure. In the tables which follow, the links between the indicators and the corresponding SDGs are shown. 


\section{Set of indicators for sustainable urban infrastructures (ISI)}
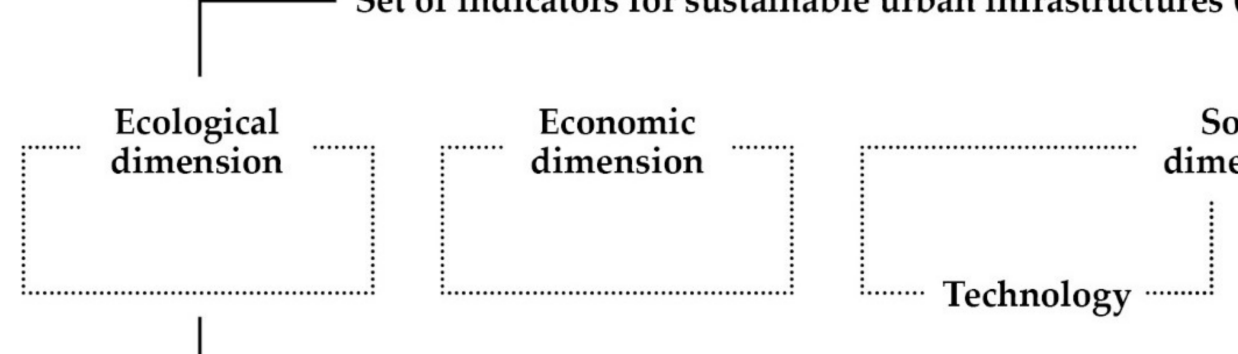

Social

Figure 1. The four pillars of ISI.

\subsubsection{Sustainability Indicators for the Ecological Dimension}

The following table (Table 1) compiles the ISI impact categories and sustainability indicators for the environmental dimension and lists the SDGs addressed.

Table 1. Impact categories and sustainability indicators for the ecological dimension.

\begin{tabular}{ccc}
\hline Impact Categories $^{1}$ & Indicators ${ }^{2}$ & SDGs \\
\hline \multirow{3}{*}{ Resources } & Use of resources & $2,6,7,9,12,15$ \\
& Use of renewable resources & $7,9,12$ \\
& Use of recyclable resources & $7,9,12$ \\
& Use of secondary resources & 9,12 \\
& Use of regional resources & $7,9,12$ \\
& Use of water & 6 \\
Land use /consumption (direct or indirect) & 2,15 \\
\hline Human health & Climate change & 3,13 \\
& Ozone depletion & 3 \\
& Photochemical ozone formation & 3 \\
Terrestrial ecosystems & Particulate matter & 3 \\
& Ionising radiation & 3 \\
& Human toxicity & 3 \\
\hline Aquatic ecosystems & Climate change & $2,13,15$ \\
& Acidification of soil & 2,15 \\
& Eutrophication of soil & 2,15 \\
& Ecotoxicity of soil & 2,15 \\
& Land use/consumption (direct or indirect) & 2,15 \\
& Biodiversity & 2,15 \\
\hline
\end{tabular}

${ }^{1}$ The level of the impact categories is inspired by the endpoint level of the impact categories in the LCA methodology [28]. ${ }^{2}$ The level of indicators corresponds to midpoint level of impact categories in LCA-Methodology [28].

\subsubsection{Sustainability Indicators for the Economic Dimension}

The table below (Table 2) compiles the ISI impact categories and sustainability indicators for the economic dimension and lists the SDGs addressed. 
Table 2. Impact categories and sustainability indicators for the economic dimension.

\begin{tabular}{|c|c|c|}
\hline Impact Categories & Indicators & SDGs \\
\hline \multirow{5}{*}{ Economic performance } & Life Cycle Costs (investment, operation, dismantling) & $1,9,11,12$ \\
\hline & Internal rate on return & $1,9,11,12$ \\
\hline & Annuity & $1,9,11,12$ \\
\hline & Payback period & $1,9,11,12$ \\
\hline & Sensitivities & $1,9,11,12$ \\
\hline Employment effects & Creation of jobs in the region & 8 \\
\hline \multirow{2}{*}{ Vulnerability } & Market and financing structures & $9,11,12$ \\
\hline & Contribution to economic independency of urban area & 11,12 \\
\hline \multirow{5}{*}{ Supply chain } & Use of renewable resources & $7,9,12$ \\
\hline & Use of fair-traded resources & $8,9,10,12$ \\
\hline & Use of recyclable resources & $7,9,12$ \\
\hline & Use of secondary resources & $7,9,12$ \\
\hline & Use of regional resources & 9,12 \\
\hline \multirow{3}{*}{ Ecosystem services } & Value of provisioning services & $2,6,7,11$ \\
\hline & Value of regulating services & $3,11,13,15$ \\
\hline & Value of cultural services & 3,11 \\
\hline
\end{tabular}

\subsubsection{Sustainability Indicators for the Social Dimension: Effects of the Technology}

The following table (Table 3) compiles the ISI impact categories and sustainability indicators for the social dimension with a focus on the effects of the technology. Similar to the tables above, the SDGs addressed are listed for each indicator.

Table 3. Impact categories and sustainability indicators for the social dimension (effects of the technology).

\begin{tabular}{|c|c|c|}
\hline Impact Categories & Indicators & SDGs \\
\hline \multirow{5}{*}{ Human health } & Premature mortality depending on air quality & 3 \\
\hline & Fine dust pollution, exposure at place of residence & 3 \\
\hline & Thermal comfort in the building (interiors) & 3,13 \\
\hline & Thermal comfort in the neighbourhood (exteriors) & 3,13 \\
\hline & Cardiovascular diseases as a result of overheating & 3,13 \\
\hline \multirow{2}{*}{ Life satisfaction } & Satisfaction with the housing situation & 3,11 \\
\hline & Satisfaction with the living environment & 3,11 \\
\hline \multirow[b]{2}{*}{ Acceptance of new technologies } & Positive basic attitude towards green, innovative technologies & 12 \\
\hline & $\begin{array}{c}\text { Increase in acceptance after the active engagement in the } \\
\text { technology development process }\end{array}$ & 12,16 \\
\hline \multirow{2}{*}{$\begin{array}{l}\text { Potential for the creation of "good" } \\
\text { jobs in the region }\end{array}$} & $\begin{array}{l}\text { Creation of future-oriented jobs and training positions with } \\
\text { good working conditions }\end{array}$ & $1,4,8,9$ \\
\hline & Creation of jobs for highly qualified employees & $1,4,8,9$ \\
\hline \multirow{3}{*}{ Implementation potential } & $\begin{array}{c}\text { Contribution of the technology to the improvement of urban } \\
\text { services and/or urban quality }\end{array}$ & $9,11,13$ \\
\hline & Feasibility in the local context & $9,11,13$ \\
\hline & Replicability and transferability to other sites & $9,10,11,12$ \\
\hline \multirow[t]{2}{*}{ Equal access to the technology } & Mass suitability of the technology & $1,6,7,9,10,11,12,16$ \\
\hline & Cost neutrality of the implemented solution & $1,6,7,9,10,11$ \\
\hline \multirow{2}{*}{ Stability of neighbourhoods } & $\begin{array}{l}\text { Displacement risk due to the implementation of the } \\
\text { technology in the local context }\end{array}$ & $10,11,16$ \\
\hline & $\begin{array}{l}\text { Decrease in fluctuation (improved image, increasing } \\
\text { satisfaction with the residential environment) }\end{array}$ & 3,11 \\
\hline
\end{tabular}




\subsubsection{Sustainability Indicators for the Social Dimension: Process and Governance System}

The following table (Table 4) compiles the ISI impact categories and sustainability indicators for the social dimension with a focus on the process and on the changes in the governance system; the table also lists the addressed SDGs for each indicator.

Table 4. Impact categories and sustainability indicators for the social dimension (process and governance system).

\begin{tabular}{|c|c|c|}
\hline Impact Categories & Indicators & SDGs \\
\hline $\begin{array}{l}\text { Engagement of the urban society in } \\
\text { the technology development process }\end{array}$ & $\begin{array}{l}\text { Involvement of stakeholders of the civil society, the public, and the } \\
\text { private sector in technology development } \\
\text { (Further) development of suitable participation instruments }\end{array}$ & $\begin{array}{c}11,16 \\
11,10,16 \\
\end{array}$ \\
\hline $\begin{array}{l}\text { Environmental education and } \\
\text { awareness raising }\end{array}$ & $\begin{array}{c}\text { Development of popular science material on the technology } \\
\text { Organisation of information events for various target groups } \\
\text { Development of teaching content (for schools, kindergartens, } \\
\text { vocational training) }\end{array}$ & $\begin{array}{l}4,9,11,12 \\
4,9,11,12 \\
4,9,11,12\end{array}$ \\
\hline $\begin{array}{c}\text { Integration of innovative } \\
\text { technologies into municipal action }\end{array}$ & $\begin{array}{l}\text { Contribution of the technology to the changing priorities in } \\
\text { consideration, planning and decision-making processes } \\
\text { Provision of funding for research and development } \\
\text { (grants, subsidies etc.) } \\
\text { private sector) } \\
\text { Pro-active investment in innovative infrastructures (public sector/ } \\
\text { Implementation of the technology in municipal facilities } \\
\text { Integration of climate, environmental and resource protection as } \\
\text { a cross-cutting issue in municipal action } \\
\text { Integration of innovative technologies in spatial and strategic } \\
\text { planning instruments }\end{array}$ & $\begin{array}{c}9,11,16 \\
4,9,11 \\
9,11,12 \\
9,11,12 \\
9,11,12,13,15,16 \\
9,11,12,16\end{array}$ \\
\hline $\begin{array}{l}\text { Enablement of the equal } \\
\text { access to the technology }\end{array}$ & $\begin{array}{c}\text { Development of policies and provision of subsidies from local, state, } \\
\text { and/ or federal government that enable access to the technology for all } \\
\text { Implementation of the technology in and on municipal residential } \\
\text { buildings (incl. social housing) }\end{array}$ & $\begin{array}{l}9,11,12,16,17 \\
9,10,11,12\end{array}$ \\
\hline $\begin{array}{l}\text { Active change of } \\
\text { consumption patterns }\end{array}$ & $\begin{array}{l}\text { Increase in demand for innovative technologies in the building sector } \\
\text { Import of fair-trade raw materials and products for the construction } \\
\text { of the technology }\end{array}$ & $\begin{array}{c}11,12 \\
8,10,12,17\end{array}$ \\
\hline $\begin{array}{l}\text { Initiation of new partnerships } \\
\text { and collaborations }\end{array}$ & $\begin{array}{c}\text { Promotion of technology solutions in global networks } \\
\text { Establishment of stable import and sales structures with emerging } \\
\text { and developing countries } \\
\text { Development of sustainable production and sales structures in the region } \\
\text { Formation of partnerships of different groups of stakeholders for } \\
\text { sustainable development and for the implementation of the } \\
\text { technology solution }\end{array}$ & $\begin{array}{c}12,17 \\
16,17 \\
8,10,12,16,17,16 \\
11,12,17\end{array}$ \\
\hline
\end{tabular}

\subsubsection{Overview of the ISI Impact Categories and Indicators}

The following table (Table 5) provides an overview of the ISI impact categories and indicators. For better readability, some of the detailed descriptions of the indicators were shortened. 
Table 5. Overview of the ISI impact categories and indicators.

\begin{tabular}{|c|c|c|c|}
\hline Ecological Dimension & Economic Dimension & $\begin{array}{l}\text { Social Dimension: } \\
\text { Technology }\end{array}$ & $\begin{array}{c}\text { Social Dimension: } \\
\text { Process and Governance }\end{array}$ \\
\hline $\begin{array}{c}\text { Resources } \\
\text { Use of resources } \\
\text { Use of renewable resources } \\
\text { Use of recyclable resources } \\
\text { Use of secondary resources } \\
\text { Use of regional resources } \\
\text { Use of water } \\
\text { Land use/consumption } \\
\text { Human health } \\
\text { Climate change } \\
\text { Ozone depletion } \\
\text { Photochemical ozone formation } \\
\text { Particulate matter } \\
\text { Ionising radiation } \\
\text { Human toxicity } \\
\text { Terrestrial ecosystems } \\
\text { Climate change } \\
\text { Acidification of soil } \\
\text { Eutrophication of soil } \\
\text { Ecotoxicity of soil } \\
\text { Land use/consumption } \\
\text { Biodiversity } \\
\text { Aquatic ecosystems } \\
\text { Eutrophication of water } \\
\text { Ecotoxicity of freshwater } \\
\text { Use of water }\end{array}$ & $\begin{array}{c}\text { Economic performance } \\
\text { Life Cycle Costs } \\
\text { Internal rate on return } \\
\text { Annuity } \\
\text { Payback period } \\
\text { Sensitivities } \\
\text { Employment effects } \\
\text { Creation of jobs in the region } \\
\text { Vulnerability } \\
\text { Market and financing structures } \\
\text { Contribution to economic } \\
\text { independency of urban area } \\
\text { Supply chain } \\
\text { Use of renewable resources } \\
\text { Use of fair-traded resources } \\
\text { Use of recyclable resources } \\
\text { Use of secondary resources } \\
\text { Use of regional resources } \\
\text { Ecosystem services } \\
\text { Value of provisioning services } \\
\text { Value of regulating services } \\
\text { Value of cultural services }\end{array}$ & $\begin{array}{c}\text { Human health } \\
\text { Premature mortality depending } \\
\text { on air quality } \\
\text { Fine dust pollution, exposure at } \\
\text { place of residence } \\
\text { Thermal comfort (interiors) } \\
\text { Thermal comfort (exteriors) } \\
\text { Cardiovascular diseases as } \\
\text { a result of overheating } \\
\text { Life satisfaction } \\
\text { Satisfaction with the } \\
\text { housing situation } \\
\text { Satisfaction with the } \\
\text { living environment } \\
\text { Acceptance of new } \\
\text { technologies } \\
\text { Positive basic attitude towards } \\
\text { green, innovative technologies } \\
\text { Increase in acceptance after the } \\
\text { active engagement } \\
\text { Potential for the creation } \\
\text { of "good" jobs in the } \\
\text { region } \\
\text { Creation of future-oriented jobs } \\
\text { and training positions (good } \\
\text { working conditions) } \\
\text { Creation of jobs for highly } \\
\text { qualified employees } \\
\text { Implementation potential } \\
\text { Improvement of urban services } \\
\text { and/or quality } \\
\text { Feasibility (local context) } \\
\text { Replicability } \\
\text { Equal access to the } \\
\text { technology } \\
\text { Mass suitability } \\
\text { Cost neutrality } \\
\text { Stability of } \\
\text { neighbourhoods } \\
\text { Displacement risk } \\
\text { Decrease in fluctuation }\end{array}$ & 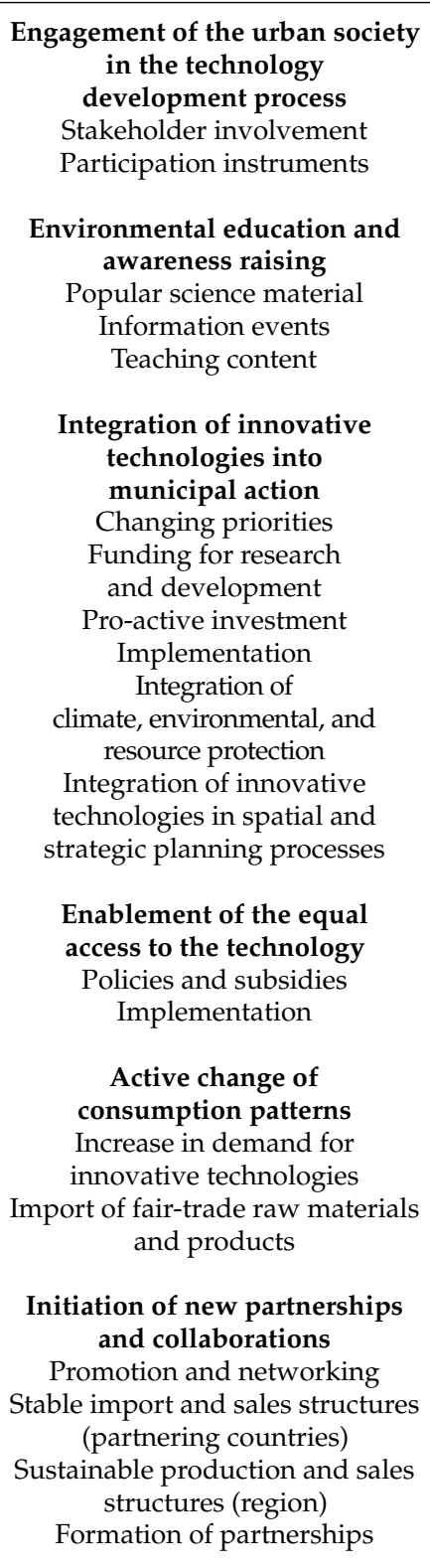 \\
\hline
\end{tabular}

To better distinguish between impact categories and indicators, the impact categories are shown in bold.

\subsection{Reflections on the Applicability of ISI to the VertiKKA Solution}

ISI was developed for the assessment of innovative urban technologies and infrastructures in general and not for the particular VertiKKA solution. Thus, ISI follows a broad approach and uses a set of indicators, which is very comprehensive. It is almost inevitable that not all indicators can be used meaningfully for every technology or infrastructure under consideration. The basic idea of ISI is that the set of indicators can be tailored to the individual case (depending on the technology, the target group, the local context, etc.).

However, the conceptualisation of ISI took place within the framework of the research project VertiKKA, therefore, the VertiKKA solution is ideal for testing the set of indicators. The VertiKKA claims to have positive impacts on the environment and on the urban society (e.g., [75]); these influences can be evaluated with the help of ISI.

In order to consider the effects of the VertiKKA solution with regard to the environmental dimension, the relevant indicators must first be selected. For VertiKKA, the use 
of resources and the climatic effects are particularly important. As the use of greywater for the irrigation of the green façade elements is a special feature of VertiKKA, additional indicators that provide information on water quality must be integrated.

Regardless of the subject of the study, data availability and quality play an essential role in the selection of indicators. Reliable data is currently still lacking for many indicators, e.g., for particulate matter uptake, NOx uptake, and ozone depletion through façade greening as well as for the influence on biodiversity. These indicators can currently only be evaluated qualitatively even though many research activities are currently taking place in this area.

It is planned to implement and test the VertiKKA at various locations in the coming years and to continue the collection of data in order to be able to make reliable quantitative statements. In addition, results and data from research projects undertaken by other institutions may contribute to the further development of ISI and to the quantification of effects.

Most indicators of the economic dimension of ISI are relevant for the evaluation of the VertiKKA. The calculation of the life cycle costs as well as the analysis of the investment with regard to payback period and annuity are of special interest for a future success of the VertiKKA.

The analysis also includes information on the performance of the different VertiKKA components. The sensitivity analysis will further determine the impact of changes in input parameters like, for instance, interest rate and electricity price on the results.

As the technology is still in the development stage, effects on regional employment and on a city's or region's economy (vulnerability) can only be estimated for certain sales scenarios. Ecosystem services that are provided by the VertiKKA include regulating and socio-cultural services. Provisioning services (such as the production of food, drinking water, or wood fuels) are not fulfilled by the VertiKKA, therefore, the valuation will be limited to the relevant services.

Since the VertiKKA project is currently still in the research and development phase, the effects of the technology on the social dimension of sustainability cannot be directly identified but must be anticipated with the help of expert opinions. For some of the impact categories, e.g., for life satisfaction and the acceptance of new technologies, however, it was possible to capture citizens' opinions and perceptions through questionnaires. However, the influence of the technology on the change of perceptions and opinions can only be determined through further survey campaigns after the completion of the implementation phase. In general, the implementation of VertiKKA and the related research in the coming years will contribute to deeper insights into the contribution of the technology to the social dimension of sustainability.

The fourth pillar of ISI, which focuses on the development process and necessary changes to the governance system, supports the review of the process and refers to necessary additional activities that are helpful for the sustainability of the technology solution and its implementation. Initially, the active participation of citizens, civil society, the private sector, and the administration in the research and development phase of VertiKKA was envisaged but could not be carried out as planned under pandemic conditions. Therefore, the stakeholder participation was limited to smaller consultation meetings and information campaigns. However, the research and implementation activities planned for the future will be accompanied by more active stakeholder work and environmental education activities.

To support the implementation of the technology after its completion, the development of conceptual approaches for the anchoring of the technology in municipal action and for the enablement of the equal access of all to the technology made up a large part of the research work. The active change of consumption patterns and the initiation of new partnerships and collaborations in connection with the VertiKKA, however, will be part of the activities, which must be addressed after the technology solution has reached market maturity. 


\subsection{Reflection on the Contribution of ISI to Sustainable and Resource-Efficient Neighbourhoods}

ISI may support urban planning processes and allows for informed decision-making as it claims to reveal strengths and weaknesses of an urban technology with regard to its suitability for sustainable and resource-efficient neighbourhoods. The set of indicators is designed in such a way that it can be used not only for an evaluation but also as a general guide for the development of urban technologies and infrastructures as it promotes systemic thinking and the consideration of side and downstream effects. ISI goes beyond the assessment of the actual technologies and infrastructures and shows the relevance of the creation process and the change of governance structures for a successful implementation and for the achievement of the sustainability goals in an urban and regional context.

\section{Discussion}

ISI seeks to provide a comprehensive assessment of the contribution of urban technologies and infrastructure to sustainable development. The set of indicators developed is based on a combination of different approaches and methods, such as LCA $[22-28,57,58]$ for the assessment of the ecological dimension, $\operatorname{LCC}[38,39,64-66]$, and RIA [33] for the assessment of the economic dimension. Furthermore, ISI focuses on the impact of innovative technologies on urban society $[51,52]$ and considers the development process and the creation of supporting governance structures [71].

ISI as such is primarily a list of relevant impact categories and indicators that allow for a comprehensive assessment of the contribution of urban technologies to sustainable development with equal consideration of the ecological, economic, and social dimension. In addition, ISI can also be used as a catalogue of criteria for the development of innovative infrastructure and technology solutions for urban areas. The application for the case of VertiKKA has shown that ISI is not (fully) applicable to every technology option and that it certainly offers scope for individual consideration.

ISI can support sustainable urban development, if the set of indicators is used for the assessment of existing and/or planned technologies and infrastructures by planners and experts; however, it is equally important that decision-makers and administrations consider the assessment results for strategic pre-planning, for the selection of appropriate technologies and for the process design.

ISI has a clear value for promoting sustainable urban development; however, there are limitations to its use in practice and its informative value, which are summarised below:

First of all, ISI was created with the participation of the practice partners but follows a purely academic approach and has not yet been tested in practice. ISI is, therefore, presented without fixed parameters, data collection, and survey methods. Consequently, for its application in the local context, the active involvement of the stakeholders to specify the indicators (and the parameters) - and the combination of indicators developed topdown and bottom-up (as suggested by Waas et al. [11])—is recommended. In a series of practical case studies, ISI will be tested for its applicability and further developed.

Secondly, the evaluation of the individual indicators is heavily based on expert knowledge. ISI, thus, promotes the active involvement of the stakeholders in the process, but also ties up working time and resources. Therefore, the challenge is to design the indicators and parameters in such a way that they can be used with as little effort as possible and with the data available in the municipalities, but without oversimplifying them and reducing their meaningfulness.

Thirdly, ISI is not designed to make a clear statement itself (or to present the supposedly most sustainable solution). Rather, it is intended to support stakeholders in consideration, planning, and decision-making processes. It reveals trade-offs on the basis of the broad set of indicators, promotes system thinking, and allows (individual) decisions. Thus, it is accepted that no truly rational decision-making takes place, but that the evaluation of the technology also takes place on the basis of politically set (sustainability) goals. In this way, ISI responds to Waas et al.'s [11] call for greater consideration of sustainability 
assessments and sustainability indicators by relevant stakeholders and decision-makers. Moreover, ISI makes references to Spangenberg and Omann [52] since it supports complex decision-making processes by incorporating different perspectives and openly accepts conflicts between the impact categories and indicators.

In addition, further research is required to develop a way to clearly present the complex results of the assessment and to make them usable for different stakeholder groups, especially for decision-makers, as a basis for discussion. Various approaches to successful communication between researchers, decision-makers, and the public can be found in the literature: Eppler [76], for example, emphasises the importance of functioning knowledge communication for the exchange between experts and decision-makers and summarizes main existing barriers. Schiller et al. [77] address the challenges that particularly affect the communication on ecological assessments and indicators and propose the development of common-language indicators as a basis for discussion. Zacks and Franconeri [78] on the other hand show the possibilities of visual communication and graph design as a support for decision-making. These approaches will be taken into account when developing a communication concept for ISI.

Author Contributions: Conceptualization, U.S. and M.T.; methodology, U.S., N.B. and M.T.; software, M.T.; validation, U.S., N.B. and M.T.; formal analysis, U.S.; investigation, N.B., M.T. and U.S.; resources, M.S.; data curation, M.T.; writing—original draft preparation, U.S., N.B. and M.T.; writing-review and editing, U.S. and M.S.; visualization, U.S.; supervision, U.S. and M.S.; project administration, M.S.; funding acquisition, M.S., U.S., M.T. and N.B. All authors have read and agreed to the published version of the manuscript.

Funding: This research was funded by the GERMAN FEDERAL MINISTRY OF EDUCATION AND RESEARCH, grant number 033W108B.

Acknowledgments: ISI was developed by the IZES gGmbH within the framework of the joint research project VertiKKA. All consortium partners, Björnsen Consulting Engineers GmbH (project lead), Photovoltaic Institute Berlin AG, ifak-Institute for Automation und Communication e. V., Bauhaus University Weimar, City of Cologne, Cologne Municipal Drainage Works (public institution), Chemnitz University of Technology, Nürtingen-Geislingen University for Business and the Environment (HfWU), participated in the discussion on the development of the approach.

Conflicts of Interest: The authors declare no conflict of interest. The funders had no role in the design of the study; in the collection, analyses, or interpretation of data; in the writing of the manuscript, or in the decision to publish the results.

\section{References}

1. Hardi, P.; Zdan, T. Assessing Sustainable Development: Principles in Practice; International Institute for Sustainable Development: Winnipeg, MB, Canada, 1997; pp. 1-166.

2. National Research Council. Our Common Journey: A Transition toward Sustainability; The National Academies Press: Washington, DC, USA, 1999.

3. Bragança, L.; Mateus, R.; Koukkari, H. Building Sustainability Assessment. Sustainability 2010, 2, 2010-2023. [CrossRef]

4. Michalina, D.; Mederly, P.; Diefenbacher, H.; Held, B. Sustainable urban development: A review of urban sustainability indicator frameworks. Sustainability 2021, 13, 9348. [CrossRef]

5. Merino-Saum, A.; Halla, P.; Superti, V.; Boesch, A.; Binder, C.R. Indicators for urban sustainability: Key lessons from a systematic analysis of 67 measurement initiatives. Ecol. Indic. 2020, 119, 106879. [CrossRef]

6. Mega, V.; Pedersen, J. Urban Sustainability Indicators; European Foundation for the Improvement of Living and Working Conditions: Dublin, Ireland, 1998.

7. López Chao, A.; Casares Gallego, A.; Lopez-Chao, V.; Alvarellos, A. Indicators framework for sustainable urban design. Atmosphere 2020, 11, 1143. [CrossRef]

8. Stanitsas, M.; Kirytopoulos, K.; Aretoulis, G. Evaluating organizational sustainability: A multi-criteria based-approach to sustainable project management indicators. Systems 2021, 9, 58. [CrossRef]

9. EEAC European Environment and Sustainable Development Advisory Councils; Working Group Governance. Impact Assessment of European Commission Policies: Achievements and Prospects-Statement of the EEAC Working Group on Governance; EEAC Office: Brussels, Belgium, 2006.

10. Berger, G. Sustainability impact assessment: European approaches. In Conducting Sustainability Assessments; OECD, Ed.; OECD Publications: Paris, France, 2008; pp. 15-34. [CrossRef] 
11. Waas, T.; Hugé, J.; Block, T.; Wright, T.; Benitez-Capistros, F.; Verbruggen, A. Sustainability assessment and indicators: Tools in a decision-making strategy for sustainable development. Sustainability 2014, 6, 5512-5534. [CrossRef]

12. WCED World Commission on Environment and Development. Our Common Future; Oxford University Press: New York, NY, USA, 1987; pp. 1-374.

13. Guinée, J.B.; Heijungs, R.; Huppes, G.; Zamagni, A.; Masoni, P.; Buonamici, R.; Ekvall, T.; Rydberg, T. Life Cycle Assessment: Past, present, and future. Environ. Sci. Technol. 2011, 45, 90-96. [CrossRef]

14. Heijungs, R.; Guinée, J.B.; Huppes, G.; Lankreijer, R.M.; de Haes, H.A.U.; Wegener Sleeswijk, A. Environmental Life Cycle Assessment of Products-Backgrounds; Centre of Environmental Science, Leiden Centrum voor Milieukunde: Leiden, The Netherlands, 1992.

15. De Haes, U.H.A.; Wrisberg, N.; Clift, R.; Frischknecht, R.; Grisel, L.; Hofstetter, P.; Jensen, A.A.; Lindfors, L.G.; Schmidt-Bleek, F.; Stiller, H. Life Cycle Assessment: State-of-the-Art and Research Priorities. Results of LCANET, a Concerted Action in the Environment and Climate Programme (DG XII)-LCA Documents; Eco-Informa Press: Bayreuth, Germany, 1997.

16. De Haes, U.H.A.; Jolliet, O.; Finnveden, G.; Hauschild, M.; Krewitt, W.; Müller-Wenk, R. Best available practice regarding impact categories and category indicators in life cycle impact assessment. Int. J. LCA 1999, 4, 66-74. [CrossRef]

17. Guinee, J.B. Handbook on life cycle assessment operational guide to the ISO standards. Int. J. LCA 2002, 7, 311. [CrossRef]

18. Guinée, J.B. Handbook on life cycle assessment-Operational guide to the ISO standards. Int. J. LCA 2001, 6, 255. [CrossRef]

19. ISO 14040:1997; Environmental Management-Life Cycle Assessment. Principles and Framework. ISO International Standard Organization: Geneva, Switzerland, 1997.

20. ISO 14040:2006; Environmental Management-Life Cycle Assessment-Principles and Framework. ISO International Standard Organization: Geneva, Switzerland, 2006.

21. ISO 14044:2006; Environmental Management-Life Cycle Assessment. Requirements and Guidelines. ISO International Standard Organization: Geneva, Switzerland, 2006.

22. EC-JRC-IES European Commission; Joint Research Centre; Institute for Environment and Sustainability. International Reference Life Cycle Data System (ILCD) Handbook. General Guide on LCA-Detailed Guidance, 1st ed.; International Reference Life Cycle Data System (ILCD), Publications Office of the European Union: Luxembourg, 2010.

23. EC-JRC-IES European Commission; Joint Research Centre; Institute for Environment and Sustainability. International Reference Life Cycle Data System (ILCD) Handbook. Review Schemes for Life Cycle Assessment, 1st ed.; Publications Office of the European Union: Luxembourg, 2010.

24. Chomkhamsri, K.; Wolf, M.; Pennington, D.; European Commission; Joint Research Centre. The International Reference Life Cycle Data System (ILCD) Handbook: Towards More Sustainable Production and Consumption for a Resource-Efficient Europe; Publications Office of the European Union: Luxembourg, 2012.

25. Sala, S.; Cerutti, A.K.; Pant, R. Development of a Weighting Approach for the Environmental Footprint; Publications Office of the European Union: Luxembourg, 2018.

26. Sala, S.; Beylot, A.; Corrado, S.; Crenna, E.; Sanyé-Mengual, E.; Secchi, M. Indicators and Assessment of the Environmental Impact of EU Consumption-Consumption and Consumer Footprints for Assessing and Monitoring EU Policies with Life Cycle Assessment; Publications Office of the European Union: Luxembourg, 2019.

27. EC-JRC-IES European Commission; Joint Research Centre; Institute for Environment and Sustainability. International Reference Life Cycle Data System (ILCD) Handbook. Framework and Requirements for Life Cycle Impact Assessment Models and Indicators, 1st ed.; Publications Office of the European Union: Luxembourg, 2010.

28. EC-JRC-IES European Commission; Joint Research Centre; Institute for Environment and Sustainability. International Reference Life Cycle Data System (ILCD) Handbook. Background Document: Analysis of Existing Environmental Impact Assessment Methodologies for use in Life Cycle Assessment, 1st ed.; Publications Office of the European Union: Luxembourg, 2010.

29. EC-JRC-IES European Commission; Joint Research Centre; Institute for Environment and Sustainability. International Reference Life Cycle Data System (ILCD) Handbook. Recommendations for Life Cycle Impact Assessment in the European context, 1st ed.; Publications Office of the European Union: Luxembourg, 2011.

30. Braune, A.; Ruiz Durán, C.; Gantner, J. Leitfaden zum Einsatz der Ökobilanzierung, 2nd ed.; DGNB e. V. Deutsche Gesellschaft für Nachhaltiges Bauen: Stuttgart, Germany, 2018.

31. Singh, R.K. Whole Building Life Cycle Assessment through LEED v4. Available online: https://gbci.org/whole-building-lifecycle-assessment-through-leed-v4 (accessed on 15 January 2022).

32. Doran, D. BREEAM-Why Whole Building Life Cycle Assessment (LCA)? BREEAM-Sustainability Assessment Method. Available online: https: / / www.breeam.com/ (accessed on 15 January 2022).

33. Carius, N.; Speck, M.; Laub, K. Regional Impact Assessment: A methodology to measure the regional value added of trans-sectoral urban planning. In Smart and Sustainable Planning for Cities and Regions; Bisello, A., Vettorato, D., Laconte, P., Costa, S., Eds.; Springer: Cham, Switzerland, 2018; pp. 253-265. [CrossRef]

34. FAO Food and Agriculture Organization of the United Nations. SAFA Guidelines: Sustainability Assessment of Food and Agriculture Systems; Version 3.0; FAO: Rome, Italy, 2014.

35. The German Federal Government. German Sustainable Development Strategy. New version 2016; The German Federal Government: Berlin, Germany, 2017.

36. The German Federal Government. German Sustainable Development Strategy, Update 2021; The German Federal Government: Berlin, Germany, 2021. 
37. Onat, N.C.; Kucukvar, M.; Halog, A.; Cloutier, S. Systems thinking for life cycle sustainability assessment: A review of recent developments, applications, and future perspectives. Sustainability 2017, 9, 706. [CrossRef]

38. Wulf, C.; Werker, J.; Ball, C.; Zapp, P.; Kuckshinrichs, W. Review of sustainability assessment approaches based on life cycles. Sustainability 2019, 11, 5717. [CrossRef]

39. Swarr, T.E.; Hunkeler, D.; Klöpffer, W.; Pesonen, H.-L.; Ciroth, A.; Brent, A.C.; Pagan, R. Environmental life-cycle costing: A code of practice. Int. J. Life Cycle Assess 2011, 16, 389-391. [CrossRef]

40. Becker, N.; Speck, M.; Trapp, M.; Laub, K. Trans-sectoral planning of waste flows in Da Nang, Vietnam: A Regional Impact Assessment. J. Urban Plan. Dev. 2022, 148(2). [CrossRef]

41. Bandanaa, J.; Asante, I.K.; Egyir, I.S.; Schader, C.; Annang, T.Y.; Blockeel, J.; Kadzere, I.; Heidenreich, A. Sustainability performance of organic and conventional cocoa farming systems in Atwima Mponua District of Ghana. Environ. Sustain. Indic. 2021, 11, 100121. [CrossRef]

42. Geneletti, D.; Bond, A.; Russel, D.; Turnpenny, J.; Sheate, W.; Jordan, A. Chapter 10: Ecosystem services and sustainability assessment: Theory and practice. In Handbook of Sustainability Assessment; Morrison-Saunders, A., Pope, J., Bond, A., Eds.; Edward Elgar Publishing: Cheltenham, UK; Northampton, MA, USA, 2015; pp. 215-234.

43. Landsberg, F.; Treweek, J.; Stickler, M.M.; Henninger, N.; Venn, O. Weaving Ecosystem Services into Impact Assessment: A Step-by-Step Method; World Resource Institute: Washington, DC, USA, 2013.

44. TEEB The Economics of Ecosystems and Biodiversity. TEEB Manual for Cities: Ecoystem Services in Urban Management; TEEB: Geneva, Switzerland, 2011.

45. Kehl, C. Inwertsetzung von Biodiversität: Endbereicht zum TA-Projekt. Arbeitsbericht Nr. 161; Büro für Technikfolgen-Abschätzung beim Deutschen Bundestag: Berlin, Germany, 2014.

46. Costanza, R.; de Groot, R.; Braat, L.; Kubiszewski, I.; Fioramonti, L.; Sutton, P.; Farber, S.; Grasso, M. Twenty years of ecosystem services: How far have we come and how far do we still need to go? Ecosyst. Serv. 2017, 28, 1-16. [CrossRef]

47. Kühnen, M.; Hahn, R. Indicators in Social Life Cycle Assessment: A review of frameworks, theories, and empirical experience. J. Ind. Ecol. 2017, 21, 1547-1565. [CrossRef]

48. Dempsey, N.; Bramley, G.; Power, S.; Brown, C. The social dimension of sustainable development: Defining urban social sustainability. Sustain. Dev. 2011, 19, 289-300. [CrossRef]

49. Woodcraft, S. Social Sustainability and new Communities: Moving from concept to practice in the UK. Procedia-Soc. Behav. Sci. 2012, 68, 29-42. [CrossRef]

50. Hagen, B.; Nassar, C.; Pijawka, D. The social dimension of sustainable neighborhood design, comparing two neighborhoods in Freiburg, Germany. Urban Plan. 2017, 2, 64-80. [CrossRef]

51. Vallance, S.; Perkins, H.C.; Dixon, J.E. What is social sustainability? A clarification of concepts. Geoforum 2011, 42, 342-348. [CrossRef]

52. Spangenberg, J.H.; Omann, I. Assessing social sustainability: Social sustainability and its multicriteria assessment in a sustainability scenario for Germany. Int. J. Innov. Sustain. Dev. 2006, 1, 318-348. [CrossRef]

53. United Nations, General Assembly. Transforming Our World: The 2030 Agenda for Sustainable Development. Resolution Adopted by the General Assembly on 25 September 2015; United Nations: New York, NY, USA, 2015.

54. BMI German Federal Ministry of the Interior, Building and Community. The New Leipzig Charter; BMI German Federal Ministry of the Interior, Building and Community: Berlin, Germany, 2020.

55. The State Government of North Rhine-Westphalia. Die globalen Nachhaltigkeitsziele Konsequent Umsetzen. Weiterentwicklung der Strategie für ein Nachhaltiges Nordrhein-Westfalen; The State Government of North Rhine-Westphalia: Düsseldorf, Germany, 2020.

56. Assmann, D.; Honold, J.; Grabow, B.; Roos, J. SDG-Indikatoren für Kommunen-Indikatoren zur Abbildung der Sustainable Development Goals der Vereinten Nationen in Deutschen Kommunen; Bertelsmann Stiftung, Bundesinstitut für Bau-, Stadt- und Raumforschung, Deutscher Landkreistag, Deutscher Städtetag, Deutscher Städte- und Gemeindebund, Deutsches Institut für Urbanistik, Engagement Global: Gütersloh, Germany, 2018.

57. ISO 14040:2021; Environmental Management-Life Cycle Assessment. Principles and Framework. ISO International Standard Organization: Geneva, Switzerland, 2021.

58. ISO 14044:2021; Environmental Management-Life cycle Assessment. Requirements and Guidelines. ISO International Standard Organization: Geneva, Switzerland, 2021.

59. CML-Department of Industrial Ecology, CML-IA Characterisation Factors. Available online: https://www.universiteitleiden.nl/ en/research/research-output/science/cml-ia-characterisation-factors (accessed on 15 January 2022).

60. Huijbregts, M.A.J.; Steinmann, Z.J.N.; Elshout, P.M.F.; Stam, G.; Verones, F.; Vieira, M.; Zijp, M.; Hollander, A.; van Zelm, R. ReCiPe2016: A harmonised life cycle impact assessment method at midpoint and endpoint level. Int. J. Life Cycle Assess 2017, 22, 138-147. [CrossRef]

61. Potting, J.; Hauschild, M. Background for Spatial Differentiation in LCA Impact Assessment-The EDIP2003 Methodology; Danish Ministry of the Environment, Danish Environmental Protection Agency: Copenhagen, Denmark, 2005.

62. Frischknecht, R.; Jungbluth, N.; Althaus, H.-J.; Bauer, C.; Doka, G.; Dones, R.; Hischier, R.; Hellweg, S.; Humbert, S.; Köllner, T.; et al. Implementation of Life Cycle Impact Assessment Methods; Ecoinvent Report No. 3; Version 2.0; Swiss Centre for Life Cycle Inventories: Dübendorf, Switzerland, 2007. 
63. Buenting, F. Lebenszykluskostenbetrachtungen bei Investitionsgüter. In Lebenszykluskosten Optimieren. Paradigmenwechsel für Anbieter und Nutzer von Investitionsgütern; Schweiger, S., Ed.; Gabler Verlag: Wiesbaden, Germany, 2009; pp. 35-50.

64. VDI-Gesellschaft Produktion und Logistik; VDI-Fachbereich Fabrikplanung und -betrieb. Purchase, operating and maintenance of production equipment using Life Cycle Costing (LCC), VDI 2884:2005. Available online: https:/ /www.vdi.de/richtlinien/details / vdi-2884-beschaffung-betrieb-und-instandhaltung-von-produktionsmitteln-unter-anwendung-von-life-cycle-costing-lcc (accessed on 19 January 2022).

65. VDMA Verband Deutscher Maschinen- und Anlagenbau e. V. Forecasting model for lifecycle costs of machines and plants, VDMA 34160:2006-06. Available online: https://www.beuth.de/de/technische-regel/vdma-34160/91838120 (accessed on 19 January 2022).

66. DIN Deutsches Institut für Normung e. V. Dependability management-Part 3-3: Application guide-Life cycle costing (IEC 56/1549/CD:2014), DIN EN 60300-3-3:2014-09, Entwurf [Draft]. Available online: https:/ /www.beuth.de/de/norm-entwurf/ din-en-60300-3-3/215774458 (accessed on 19 January 2022).

67. Plinke, W.; Utzig, B.P. Industrielle Kostenrechnung: Eine Einführung, 9th ed.; Springer Vieweg: Berlin/Heidelberg, Germany, 2020.

68. United Nations Decade on Ecosystem Restoration 2021-2030. Available online: https://www.decadeonrestoration.org/ (accessed on 21 December 2021).

69. Ott, K.; Doering, R. Theorie und Praxis starker Nachhaltigkeit. Beitraege zur Theorie und Praxis starker Nachhaltigkeit. Band 1, 3rd ed.; Metropolis Verlag: Marburg, Germany, 2008.

70. Crabtree, L. Sustainable housing development in urban Australia: Exploring obstacles to and opportunities for ecocity efforts. Aust. Geogr. 2005, 36, 333-350. [CrossRef]

71. Kanie, N.; Zondervan, R.; Stevens, C. Ideas on Governance 'of' and 'for' Sustainable Development Goals: UNU-IAS/POST2015. Conference Report; United Nations University, Institute for the Advanced Study of Sustainability (UNU-IAS): Tokyo, Japan, 2014.

72. Glass, L.-M.; Newig, J. Governance for achieving the Sustainable Development Goals: How important are participation, policy coherence, reflexivity, adaptation and democratic institutions? Earth Syst. Gov. 2019, 2, 100031. [CrossRef]

73. Weterings, R. Indicatoren voor Duurzame Ontwikkeling; RMNO Raad voor Natuur- en Milieuonderzoek: Rijswijk, The Netherlands, 1993.

74. Meadows, D. Indicators and Information Systems for Sustainable Development-A Report to the Balaton Group; The Sustainability Institute: Hartland, VT, USA, 1998.

75. Middendorf, V.; Becker, N.; Schulz, M. Vertikale Klima-Klär-Anlage: Grauwasserreinigung und -nutzung durch Fassadenbegrünung. Transform. Cities 2021, 3, 20-21.

76. Eppler, M.J. Knowledge communication problems between experts and decision makers: An overview and classification. Electron. J. Knowl. Manag. 2007, 5, 291-300.

77. Schiller, A.; Hunsaker, C.T.; Kane, M.A.; Wolfe, A.K.; Dale, V.H.; Suter, G.W.; Russell, C.S.; Pion, G.; Jensen, M.H.; Konar, V.C. Communicating ecological indicators to decision makers and the public. Conserv. Ecol. 2001, 5, 19. [CrossRef]

78. Zacks, J.M.; Franconeri, S.L. Designing graphs for decision-makers. Policy Insights Behav. Brain Sci. 2020, 7, 52-63. [CrossRef] 